\title{
HUKUMAN POTONG TANGAN PERSPEKTIF AL-QUR'AN DAN HADIS
}

\author{
Nailul Rahmi \\ Dosen Fakultas Syaria'ah UIN Imam Bonjol Padang
}

\begin{abstract}
Abstrak
Salah satu dari ketentuan hukum jinayah dalam hukum Islam adalah bahwa siapapun yang mencuri harta orang lain maka pelakunya diberi sanksi hukuman yaitu hukuman had potong tangan seperti yang dijelaskan dalam ayat 38 dari surat al-Maidah di atas. Kemudian yang pelaksanaannya dijelaskan dalam hadits-hadits Rasul Saw. Dengan demikian penetapan had potong tangan bagi pencuri tujuannya adalah untuk memberikan jaminan kemaslahatan terhadap harta manusia dari kerusakan, kehancuran dan dari kepemilikan yang tidak dibenarkan Islam dari pihak lain.
\end{abstract}

Kata Kunci: Potong tangan,Al-Qur`an dan Hadis

\section{PENDAHULUAN}

Al-Quran adalah kalamullah yang diturunkan kepada RasulNya yang terakhir Muhammad Saw untuk menjadi al-Hudan dan al-Furqan bagi umat manusia dalam kehidupannya di bumi Allah ini. Oleh karena itu Allah menetapkan bermacam ketentuanketentuan yang harus dilaksanakan oleh manusia jika mereka ingin hidup dengan sejahtera baik di dunia ataupun di akhirat kelak. Sebagai kitab suci yang berisi petunjuk bagi manusia, alQur'an mengandung berbagai hal. Secara global al-Quran mencakup tentang aqidah, ibadab, mu'amalah, jinayah, munakahah dan waris.(selain aqidah biasa disebut Syari'ah), qisahqisah, akhlaq, wa'ad dan wa'id..

Al-Quran diturunkan Allah dengan bahasa $A{ }^{1}{ }^{1}$ sehingga tidak semua orang dapat memahaminya dengan mudah bahkan orang Arab sendiri

\footnotetext{
${ }^{1}$ Q.S.12(Yusuf): 12 :
}

orang yang bahasa mereka menjadi bahasa al-Quran. Untuk dapat memahami isi dan pesan-pesan alQur'an, maka seseorang dituntut untuk memahami bahasa al-Qur'an. Artinya siapa saja yang ingin mengkaji alQur'an maka ia harus mengkaji bahasa al-Qur'an. Tanpa memahami bahasa Al-Qur'an tidak mungkin mampu mengambil dan mengamalkan isi alQur'an.

Dalam rangka memahami dan menjelaskan isi dan kandungan alQuran maka Allah Swt menugaskan kepada RasulNya untuk menjelaskan atau menafsirkan al-Qur.an. Namun setelah beliau wafat tugas ini diemban oleh para ulama dari kalangan sahahabatnya.

- Setelah masa sahabat penjelasan dan penafsiran al-Qur'an dilakukan oleh ulama tabi'in begitulah selanjutnya alQuran dikaji oleh para tabi' tabi' in dan akhirnya sampai pada masa sekarang. Bermacam metode yang digunakan 
oleh para ulama untuk menafsirkan alQur'an, seperti metode tafsir bi almaktsur, metode bi al-ra'yu, metode isyari. Ini adalah metode yang didasarkan pada sumber penafsiran. Selain metode tersebut ada lagi yang disebut metode tahlili, metode ijmali, metode maudhu'i dan metode muqarran. Ini adalah metode penafsiran berdasarkan keluasan penafsiran dan sistematika ayat yang ditafsirkan.

Dalam menafsirkan al-Qur'an para ulama juga dipengaruhi oleh kecendrungan keilmuan yang dimiliki serta keluasan wawasan terhadap masalah kajian yang dicakup ayat. Oleh karena itu para ulama menetapkan beberapa syarat yang mesti dimiliki oleh seseorang jika dia ingin menafsirkan al-Qur'an, baik syarat yang berhubungan dengan etika dalam menafsirkan ataupun syarat yang berhubungan dengan ilmu-ilmu yang harus dimiliki. Selain itu juga harus mengetahui kaedah-kaedah tafsir, baik kaedah dasar ataupun kaedah kebahasaan. Tanpa memiliki pengetahuan seperti yang dijelaskan di atas maka seseorang tidak mungkin dapat menjelaskan ayat-ayat al-Qur'an dengan baik dan benar.

Namun jika semua syarat-syarat tersebut belum dimiliki secara maksimal bukan berarti seseorang tidak dapat memahami penafsiran ayat-ayat al-Qur'an, karena untuk memahami penafsiran ayat-ayat al-Qur'an dapat dilakukan dengan menela'ah kitabkitab tafsir karya para mufassir yang sudah ada. Sebab bagaimanpun bagi seorang muslim wajib memahami maksud dan isi al-Quran karena alQur'an adalah petunjuk dalam menjalani kehidupan untuk kebahagiaan di dunia dan di akhirat kelak. Berhubungan dengan hal tersebut sesuai dengan kapasitas penulis yang belum memenuhi syaratsyarat sebagai mufassir, maka penulis mencoba menela'ah dan memahami pesan-pesan al-Qur'an melalui kajian terhadap penafsiran yang sudah dilakukan oleh para mufasir sebelumnya. Adapun ayat yang akan dikaji di sini hanyalah ayat yang menjelaskan tentang had potong tangan bagi pencuri yang terdapat pada ayat 38 surat al-Maidah. Pemilihan ayat ini sebagai kajian karena pada ayat ini dijelskan had bagi pencuri adalah potong tangan, tetapi bagian yang mana yang dipotong tidak dijelaskan, apa yang dicuri dan berapa kadar curian yang menyebabkan had ini dilakukan juga tidak dijelaskan.

Kemudian dalam ayat juga tidak dijelaskan adanya pengecualiapengecualian hukum had ini. Tetapi dalam sejarah umat Islam, Umar bi Khatab pernah tidak meksanakan had tersebut bagi pencuri yang mencuri pada masa paceklik.

Berhubungan dengan hal-hal tersebut penulis tertarik untuk mengkaji penafsiran ayat ini berdasarkan penafsiran-penafsiran para mufassir dari berbagai kitab tafsir dan penjelasan hadits-hadits tentang masalah pencurian dan hukuman potongan tangan bagi pencuri.

\section{Pembahasan}

1. Ayat 38 surat al-Maidah.

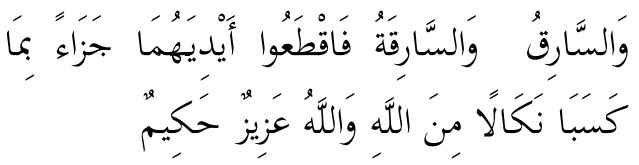

Laki-laki yang mencuri dan perempuan yang mencuri, potonglah tangan keduanya (sebagai) pembalasan bagi apa yang mereka kerjakan dan sebagai 
siksaan dari Allah. dan Allah Maha Perkasa lagi Maha Bijaksana..

2. Mufradat

Lafaz artinya orang yang mengambil harta secara sembunyisembunyi dari tempat penyimpanannya.ia adalah isim fa'il dari lafaz yang artinya mencuri atau mengambil sesuatu yang dilakukan secara sembunyi-sembunyi dari tempat penyimpanan.Termasuk dalam pencurian adalah mencuri dengar pembicaraan orang lain dan mencuri pandang jika dilakukan dengan sembunyi-sembunyi. ${ }^{2}$ Sariq artinya pencuri laki-laki atau ada yang mengartikan laki-laki pencuri dan sariqah pencuri perempuan atau فاطعوا أيديهيا perempuan pencuri. tempat pemotongan dari tangan artinya tempat pada bagian tangan yang dipotong jika seseorang mencuri. Orang yang dipotong tangannya jika dia mencuri $1 / 4$ dinar menurut jumhur selain hanafiah. sanksi atau hukuman bagi keduanya (pencuri baik ia laki-laki ataupun perempuan) untuk menghalangi atau larangan bagi manusia untuk melakukan pencurian ${ }^{3}$. Hukuman dari Allah terhadap perbuatan pencurian yang dilarang Allah Swt. Oleh karena itu hukuman had potong tangan bagi pencuri tidak dapat gugur karena ma'af yang

Wahbah al-Zuhaili, Figh al Islam wa Adillatuhu, Dar al-Fikr, Beirut, 1989, juz 6, h. 92. Lihat juga Abdullah bin Abdu ar-Rahman al-Basami, Tudhihu al-Ahkam min Bulugh alMaram, t.t. juz. Iv, h. 180.

${ }^{3}$ Wahbah Zuhaili,Tafsir al-Munir fi al-'Aqidah wa al-Syari'ah, Dar al-Fikr, Beirut, jilid 5 t.t. h. 178 . diberikan oleh pemilik harta yang dicuri. ${ }^{4}$

\section{Asbab al-Nuzul}

Diriwayatkan oleh Ahmad dan yang lainnya yang bersumber dari Abdullah bin Amr bahwa seorang wanita mencuri dimassa Rasulullah Saw, kemudian dipotong tangannya yang kanan (sesuai s.5:38). Ia bertanya: apakah diterima taubatku ya Rasulullah? Maka Allah menurunkan ayat berikutnya (s.5:39) ${ }^{5}$. Kemudian alAmidi menjelaskan bahwa asbabun nuzul ayat ini berhubungan dengan Thu'man bin Ubairq ketika mencuri baju besi tetangganya yang disembunyikan dalam tepung gandum. kemudian didakwakannya kepada Qutadah bin Nu'man, Dia menyembunyikan di rumah seorang Yahudi Zaid bin Saminn . Ketika dituduhkan kepada Qutadah sebagai pencuri seperti tuduhan Thu'mah, tidak ditemukan padanya tuduhan tersebut. Dia membantah tidak mengambilnya, dia tidak tahu sama sekali. Kemudian ditelusuri tepung yang tercecer dan diikuti sehingga sampai kerumah Zaid bin Samin lalu diambil darinya dan berkata : "Serahkanlah kepada Thu'mah!" Yahudi itu disaksikan oleh orang banyak. Rasul Saw telah diragukan oleh perdebatan Thu'mah, sebab baju besi ditemukan pada orang lain. Maka turnlah ayat : و لاتجادل عن الذين يختانون kemudian diturunkan ayat ini

\footnotetext{
4 Muhammad Jamaluddin Al-Qasimy, Tafdsir Al-Qasimy al-Musamma Mahasi alTakwil, Dar al-Fikr, Beirut, Juz. 6, h. 196.

5 Qamarudin Saleh dkk. Asbabun Nuzul, CV.Diponegoro, Bandung, 1984, h. 181 lihat juga Al-Sayuthi, Asbab al-Nuzul.
} 
untuk menjelaskan tentang hukum pencurian. ${ }^{6}$

\section{Munasabah}

Pada ayat 37 Allah menjelaskan tentang . hukum bagi orang yang mengambil harta orang lain dengan hirabah atau penyamun atau perampok, yaitu dengan memotong atau merampas orang ditengah jalan dengan kekerasan, adakalanya dengan menyakiti pemilik harta atau bahkan dengan membunuh pemilik harta. Menurut Abu Hanifah hirabah adalah pencurian yang besar, sedangkan menurut yang lain pencurian kecil. Setelah Allah menjelaskan sanksi bagi pelaku hirabah yang melakuka perbuatan yang fasad di atas bumi dan menyuruh manusia untuk bertaqwa kepada Allah agar terhindar dari perbuatan yang haram dan ma'shiat, lalu Allah menjelaskan sanksi bagi orang-orang yang mengambil harta dari persembunyiannya. Diantara sanksi pagi pelaku hirabah adalah dipotong tangan dan kaki secara berlawanan dan sanksi pencurian adalah potong tangan. Kemudian pada ayat 39 Allah menjelaskan bahwa Dia akan mengampuni hambaNya yang bertaubat setelah melakukan perbuatan dosa. Hirabah dan pencurian adalah perbuataan dosa yang dilarang oleh Allah Swt, dan siapa saja yang melakukannya maka Allah telah menetapkan sanksi bagi mereka di dunia dan akhirat kelak, karena itu seyogyanyalah perbuatan tersebut selalu dihindari oleh seorang mukmin.

6 AL Al-Amidy, Asbab al-Nuzul. Lihat juga Abi al-hasan Ali bin Ahmad alWahidy al-Naisabury, Asbab a-Nuzul, Dar alFkri, Beirut, 1991, h. 125 dan Qamaruddin Saleh dkk, Asbabun Nuzul, CV Diponegoro, Bandung, 1984, h. 181.
5. Hadits-Hadits tentang Had Potong Tangan bagi Pencuri

Hadits-hadits yang menjelaskan hukuman potong tangan bagi pencuri ada beberapa buah, antara lain yaitu: ${ }^{7}$

a. Hadits Aisyah R.a

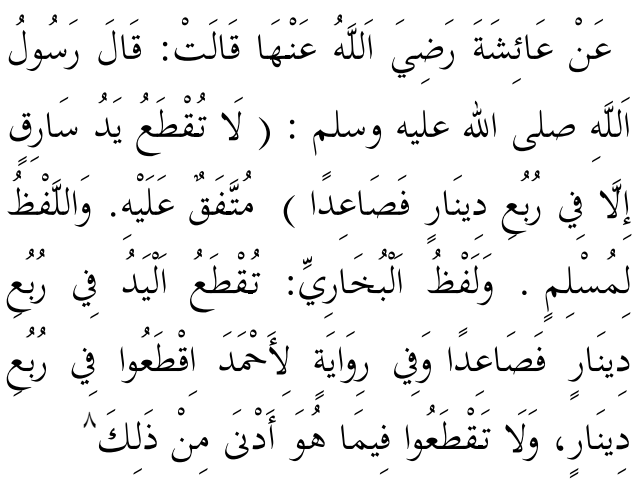

Dari 'Aisyah bahwa Rasulullah Shallallaahu 'alaihi wa Sallam bersabda: "Tidak boleh dipotong tangan seorang pencuri, kecuali sebesar seperempat dinar atau lebih." Muttafaq Alaihi dan lafadznya menurut riwayat Muslim. Menurut Lafadz Bukhari: "Tangan seorang pencuri dipotong (jika mengambil sebesar seperempat dinar atau lebih." Menurut riwayat Ahmad: "Potonglah jika mengambil seperempat

7 Hafiz Ibnu Hajar al-Asqalany, Bulughul Maram, terjm. M.Syarif Sukandy, PT Al-Ma'arif, Bandung, 1995, h. 458-462. Lihat juga Malik bin Anas, al-Muaththa', Dar al-Fkr, Beirut, tt.h. 508-5-14.

${ }^{8}$ Muhammad bin Isma'il al-Amir alYamaniy al-Shan'ani, Subulussalam syarah Bulughul Maram, Syirkah Maktabah wa Mathba'ah Musthafa al-Baby alHalaby wa Awladihi, Mesir, 1950, juz. 4, h. 18. Lihat Shahih al-Bukhary dalam bab hudud (no 6789), Shahih Muslim bab hudud (no 1684), Sunan Nasa'i bab qath'u al-Sariq no 4936, Sunan Ibnu Majah bab had al-Sariq (no 2585), Sunan Abu Daud n0 (2348) dan Musnad Ahmad (no 23558) pada bab al-Irwa'a (2024). 
dinar dan jangan memotong jika mengambil lebih kurang daripada itu."

b. Hadits Ibnu Umar r.a.

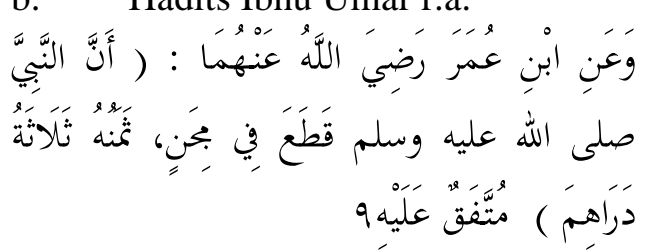

Dari Ibnu Umar Radliyallaahu 'anhu bahwa Nabi Shallallaahu 'alaihi wa Sallam pernah memotong (tangan pencuri) karena mengambil sebual perisai seharga tiga dirham. Muttafaq Alaihi.

\section{c. Hadits Abu Hurairah RA}

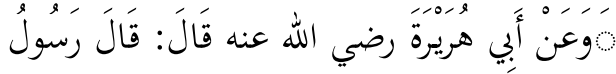

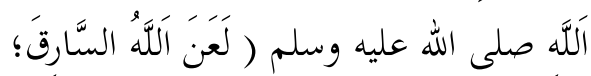

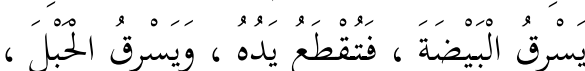

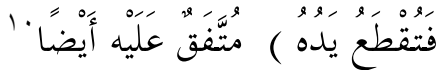

Dari Abu Hurairah Radliyallaahu 'anhu bahwa Rasulullah Shallallaahu 'alaihi wa Sallam bersabda: "Allah melaknat pencuri yang mencuri telur kemudian dipotong tangannya, lalu mencuri tali dan dipotong tangannya." Muttafaq Alaihi.

d. Hadits Aisyah r.a.

\footnotetext{
9 Hafiz Ibnu Hajar al-Asqalany, Op.cit. h.458. lihat juga Muhammad Nasiruddin al-al-Bani, Shahih Sunan Abu Daud, juz. 12, h. 83-90.

${ }^{10}$ Imam Abi Abdillah Muhammad Bin Isma'il abin Ibrahim Ibnu Mughirah bin Bardaziyah al-Bukhary, Shahih al Bukhary, Maktabah Usaha Keluarga, Semarang, 1981, juz. 8. H. 15 .
}

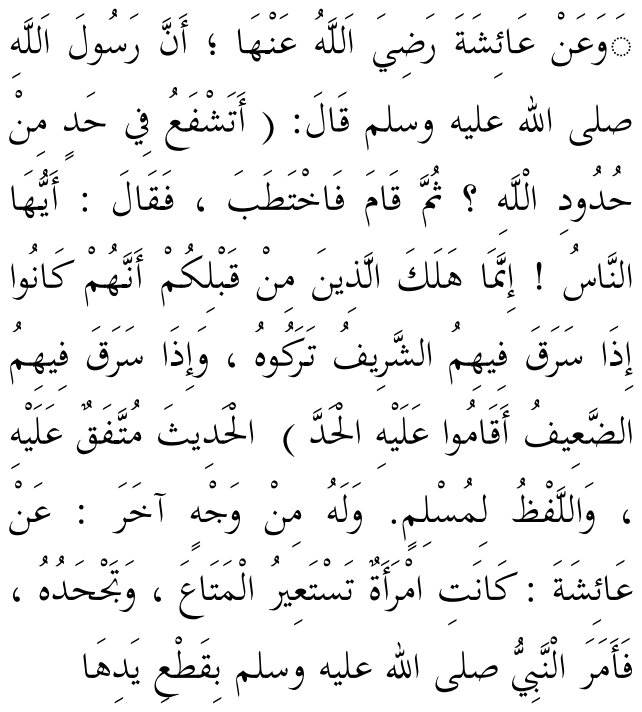

Dari 'Aisyah Radliyallaahu 'anhu bahwa Rasulullah Shallallaahu 'alaihi wa Sallam bersabda: "Apakah engkau akan memberikan pertolongan untuk membebaskan suatu hukuman dari hukum-hukum yang telah ditetapkan Allah?". Kemudian beliau berdiri dan berkhutbah. Beliau bersabda: "Wahai manusia, orang-orang sebelummu binasa adalah karena jika ada seseorang yang terpandang di antara mereka mencuri, mereka membebaskannya, dan jika ada orang lemah di antara mereka mencuri, mereka menegakkan hukum padanya." Muttafaq Alaihi dan lafadznya menurut riwayat Muslim. Menurut riwayatnya dari jalan lain bahwa 'Aisyah Radliyallaahu 'anhu berkata: Ada seorang perempuan meminjam barang lalu memungkirinya, maka Nabi Shallallaahu 'alaihi wa Sallam memerintahkan untuk memotong tangannya.

e. Hadits Jabir r.a.

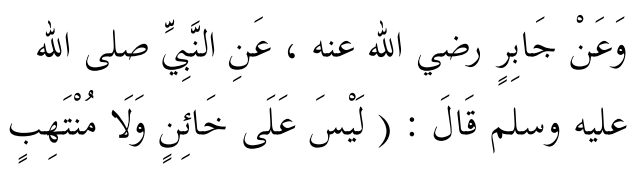




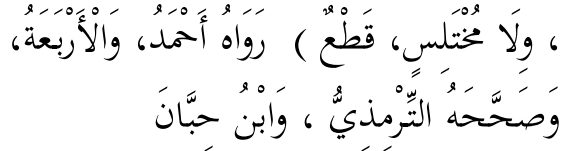

Dari Jabir Radliyallaahu 'anhu bahwa Rasulullah Shallallaahu 'alaihi wa Sallam bersabda: "Pengkhianat, pencopet, dan perampok tidak dikenakan hukuman potong." Riwayat Ahmad dan Imam Empat. Hadits shahih menurut Tirmidzi dan Ibnu Hibban.

\section{f. Hadits Rafi' bin Khadij r.a.}

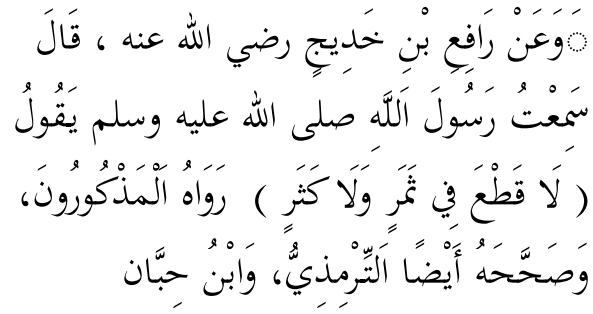

Rafi' Ibnu Khodij Radliyallaahu 'anhu berkata: Aku mendengar Rasulullah Shallallaahu 'alaihi wa Sallam bersabda: "Tidak dipotong orang yang mencuri buah dan mayang kurma." Diriwayatkan oleh Ahmad dan Imam Empat. Hadits shahih juga menurut Tirmidzi dan Ibnu Hibban.

6. Penafsiran

Ayat رق و السارقة فاقطعوا أيديهما menjelaskan bahwa seorang laki-laki pencuri dan seorang perempuan pencuri maka hendaklah dipotong tangan keduanya. Allah menjelaskan dalam ayat ini bahwa siapapun yang mencuri hendaklah tangannya dipotong, penjelasan ini tidak membedakan antara laki-laki dengan perempuan. Di sini Allah menyebutkan "al-sariq" lebih dulu dari "al-sariqah" kebalikan dari ayat zina. Semua mufassir sepakat dalam hal ini. Jika diperhatikan ayat yang menggunakan lafaz pencuri isim fa'il dari saraqa ini memberikan indikasi bahwa seseorang tersebut telah berulang-ulang melakukan pencurian, sehingga wajar diberi sanksi potong tangan. Artinya Allah juga membedakan antara seorang pencuri dengan orang yang mencuri.

Abdullah bin Abdurrahman as-Sahmy menjelaskan bahwa al-sirqah (pencurian) menurut bahasa adalah mengambil sesuatu secara sembunyisembunyi dari tempat penyimpanan, Sedangkan menurut istilah yaitu mengambil harta yang dipelihara dari orang lain dari tempat penyimpanannya, yang tidak diragukan lagi padanya untuk disembunyikan. ${ }^{11}$ Didahulukan penyebutan sariq dari pada sariqah menurut al-Shabuni adalah karena pencurian biasanya dilakukan oleh laki-laki, sedangkan didahulukan zaniyah dari zani pada ayat zina karena buruknya akibat zina bagi perempuan. ${ }^{12}$

Menurut al-Qurthubi sejak massa jahiliah potong tangan bagi pencuri sudah terjadi. Dan pencuri yang pertama dihukum dengan potong tangan pada masa jahiliah adalah Walid bin Mughirah. Kemudian Allah juga menetapkan hukuman potong tangan dalam Islam. Pencuri pertama yang dipotong tangannya oleh Rasul Saw pada masa Islam dari kaum laki-laki adalah Khiyar bin "Adi bin Naufal bin "Abdi Manaf. Sedangkan dari kalangan perempuan adalah Marrah binti Sufyanbin Abdi al-Asaddari Bani Makhzum. Abu Bakar juga pernah

11 Abdullah bin Abdurrahman alSammy, Tudhihual-Ahkam min Bulughul Maram. Juz . 4, h. 181. Selanjutnya disebu AsSammi.

${ }^{12}$ Muhammad Ali Al-Shabuni, Rawai' al-Bayan Tafsir Ayat al-Ahkam min al-Qur'an, Dar al-Kutub al-Islamiyah, Makkah, juz I, h. 435. 
memotong tangan orang Yaman yang mencuri sebuah kalung dan kalung yang dicuri tersebut adalah kalung Asma' binti Umair, istri Abu Bakar r.a. Kemudian Umar juga pernah memotong tangan Ibnu Samurah, saudara Abdurrahman bin Samurrah, dan tindakan ini merupakan sesuatu hal yang tidak pernah diperselisihkan. ${ }^{13}$

Ayat ini secara zahir menunjukkan bahwa semua orang yang mencuri dikenai hukuman potong tangan baik laki-laki ataupun perempuan, sama seperti yang terjadi pada pezina bahwa siapapun yang berzina maka ia dihukum dengan hukuman jilid 100 kali. Ayat tentang hukuman potong tangan bagi seorang pencuri dalam surat al-Maidah ayat 38 ini dari segi makna lafaz adalah mutlaq sebab siapa saja yang mencuri maka pencuri tersebut dipotong tangannya. Dari segi dalalah ayat ini juga mujmal karema tidak dijelaskan apa yang dicuri dan bagaimana ukuran barang curian yang dapat diberi sanksi potong tangan. Oleh karena itu para mufassir dan fuqaha berbeda pendapat tentang beberapa masalah yang terkandung dalam ayat ini, diantaranya yaitu tentang pencuri yang dipotong tangannya, kedua tentang nisab harta curian yang menyebabkan potong tangan, ketiga tentang tempat penyimpanan barang yang dicuri, keempat tentang pencurian yang dilakukan secara bersama apakah semua pencuri dipotong tangannya, pencuri harta masjid dan harta mayat dalam kuburan dan tentang pencuri yang telah dipotong tangan kanannya lalu dia mencuri lagi dan masalahmasalah lain yang berkaitan dengan pencurian.

\footnotetext{
${ }^{13}$ Abdillah Muhammad bin Ahmad alAnshary al-Qurthubi, Al-Jami' li Ahkam alQur'an, Dar al-Fikr, Beirut, tt. juz 5, h. 111.
}

Masalah pertama tentang pencuri yang dipotong tangannya, dan tentang hal ini para ulama berbeda pendapat, karena itu akan dikemukakan pendapat tersebut dengan dalilnya masing-masing. Pertama jumhur ulama yang berpendapat bahwa hukuman potong tangan hanya dilaksanakan kepada pencuri yang harta curiannya sampai seperempat dinar atau yang nilainya seperempat mitsqal emas murni (1/4 mitsqal emas setara dengan 0,9695 gram) atau tiga dirham perak ( 3 dirham perak setara dengan 8,145 gram) berdasarkan hadits Aisyah. Kedua golongan zahiriyah yang berpendapat bahwa hukuman potong tangan dilaksanakan kepada pencuri berapapun harta yang dicurinya baik sedikit ataupun banyak sesuai dengan keumuman ayat. Ketiga ulama Hanafiah yang berpendapat bahwa bukuman potong tangan hanya dilakukan bagi pencuri yang harta curiannya sampai 10 dirham atau lebih (10 dirham perak setara dengan 27, 15 garam), dan tidak boleh kurang dari itu. Keempat segolongan ahli Madinah, diantaranya Malik bin Anas, berpendapat bahwa pencuri yang dipotong tangannya adalah yang mencuri sejumlah tiga dirham atau lebih.

Secara bahasa adalah nama atau sebutan yang diberikan kepada orang yang mengambil harta dari tempat penyimpanannya. Secara istilah yaitu orang yang mengambil harta yang dipelihara dari orang lain, yaitu pada tempat penyimpanan yang tersembunyi. ${ }^{14}$ Perbuatan mengambil milik atau harta orang lain dari tempat persembunyiannya, yang mana pemilik harta tidak mengizinkan siapapun 
mengambilnya, maka perbuatan tersebut dinamakan mencuri (sirqah). Karena itu siapa saja yang mengambil milik orang lain dari tempat persembunyiannya sedangkan dia tidak diizinkan kesana maka orang tersebut dinamakan pencuri baik dia laki-laki ataupun perempuan. Artinya seseorang disebut pencuri jika mengambil harta orang lain, harta yang dicuri diletakkan pada tempat yang tersembunyi dan perbuatan mengambil milik orang lain tersebut dilakukan secara sembunyisembunyi. Oleh karena itu orang yang mengambil harta orang lain tidak dari tempat persembunyiannya dan dilakukan secara terang-terangan tidak disebut pencuri sebagaimana ayat sebelumnya yang menyebut orang yang mengambil harta orang lain dengan kekerasan dari tangan pemiliknya disebut hirabah atau perampok.

Menurut al-Razi ayat dibaca marfu' oleh Sibawaihi dan Akhfasy sebagai mubtada sedangkan khabarnya adalah mahzuf dan taqdirnya "hukmuhuma" Pendapat ini juga dipilih olehn al-Farra', bahwa membacanya dengan marfu' lebih utama daripada membaca dengan nasab. Sebab alif dan lam pada lafaz alsariq dan al-sariqatu menempati tempat allazi sehingga taqdirnya سرق فا قطعوا يده , dan menempatkan fa pada khabar karena ia menjadi jaza'.

Jadi maksud ayat menurut al-Razi adalah menunjukkan bahwa syarat dan jaza' atau balasan bagi pencuri disyari'atkan adalah karena perbuatan pencurian yang dilakukan. Kemudian ayat menunjukkan bahwa sirqah (pencurian) adalah suatu jinayah dan potong tangan adalah hukumannya, "uqubah dihubungkan dengan adanya jinayah adalah munasabah antara keduanya. Disebutkan hukum 'uqubah dan sifat yang sesuai menunjukkan bahwa sifat tersebut merupakan 'illat bagi hukum tersebut. ${ }^{15}$

Menurut al-Qurthubi pencuri yang dipotong tangannya adalah pencuri yang harta curiannya mencapai seperempat dinar atau yang nilainya sama dengan seperempat dinar. Ini adalah pendapat Umar bin Khathab, Utsman bin Affan yang diriwayatkan dari Ali. Pendapat ini juga dikemukakan oleh Umar bin Abdul Aziz, Al-Laits, Asy-Syafi'i dan Abu Tsur. ${ }^{16}$ Imam Malik juga berpendapat demikian bahkan bagi orang yang mencuri dua dirham, sebab dua dirham sama nilainya dengan seperempat dinar. Jika kurang dari nilai tersebut maka tidak berlaku hukuman potong tangan.

Masalah kedua Ayat menjelaskan bahwa pencuri harus dipotong tangannya, namun ayat tidak menjelaskan apa yang dicuri dan berapa harta yang dicuri baru dilakukan hukuman potong tangan kepada seorang pencuri. Rasul Saw kemudian menjelaskan syarat dilakukannya potong tangan pada pencuri. Riwayat dari Aisyah r.s. menjelaskan :

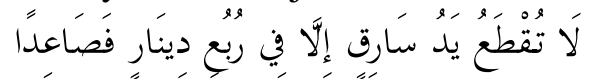

"Tidaklah dipotong tangan seorang pencuri kecuali jika dia mencuri seperempat dinar atau lebih dari seperempat dinar " H.R. Muttafaq 'alaih. Ini lafaz Muslim, sedangkan

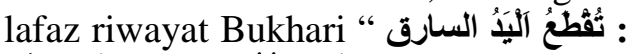

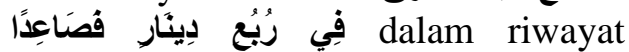

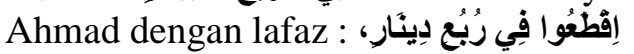

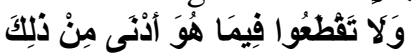

Hadits Aisyah menjelaskan bahwa hukuman potong tangan dilakukan jika harta yang dicuri jumlahnya sampai

$$
{ }^{15} \text { Ibid h. } 111 .
$$


seperempat dinar ${ }^{17}$ atau lebih. Pendapat yang mensyaratkan hukuman potong tangan bagi pencuri jika ia mencuri seperempat dinar menjadikan hadits yang dikemukakan Aisyah r.a sebagai dalilnya. Riwayat Muslim yang bersumber dari Aisyah menjelaskan bahwa Rasul Saw telah bersabda "Tidaklah dipotong tangan seorang pencuri kecuali pada barang curian seperempat dinar atau lebih" sedangkan pada Bukhari "dipotong tangan pencuri pada curian seperempat dinar atau lebih. Dalam riwayat Ahmad "Potonglah oleh kamu tangan pencuri pada curian seperempat dinar dan jangan dipotong pada barang curian yang kurang dari itu"18 Artinya bahwa jumlah nishab harta barang curian untuk dilakukan had potong tangan adalah seperempat dinar. Jika harta curian tersebut kurang dari seperempat dinar atau tiga dirham sebagimana hadits Ibnu Umar, maka tidak diperlakukan had potong tangan bagi pencuri sebagaimana dalam riwayat Ahmad.

Al-Qasimi menjelaskan bahwa menurut Imam Syafi'i, Imam Ahmad dan Ishaq bahwa seperempat dinar dan tiga dirham itu sifatnya syar'i, dan satu dinar itu setara dengan dua belas dirham. Dan juga riwayat dari Aisyah menjelaskan bahwa pencuri yang mencuri perisai yang dipotong tangannya karena harga perisai tersebut setara dengan seperempat dinar, tidak sepuluh dirham. ${ }^{19}$

17 Dinar adalah ukuran dari emas beratnya (timbangannya adalah $4 \mathrm{~g}$, yaitu seperempat dari mas murni. Lihat Abdullah bin Abdu ar-Rahman al-Basami. Loc.cit.

18 Abdullah bin Abdurrahman alBasssam, Tudhahu al-Ahkam min Bulugh al Maram,

\footnotetext{
${ }^{19}$ A-.Qasimy, op.cit. h. 195.
}

Adapun Hasan al-Bashry dan Abu Daud az-Zahiry serta sebahagian fuqaha' ahli Zahir berpendapat bahwa bila seorang pencuri mencuri sesuatu maka dipotong tangannya baik dia mencuri sedikit ataupun banyak karena keumuman ayat ini : Seorang pencuri baik laki-laki ataupun perempuan maka potonglah tangan keduanya", dalam ayat ini tidak ada penjelasan nisab dari barang curian dan juga tidak dijelaskan tempat penyimpanan, tetapi mereka mengambil semata-mata pencurian.

Dalilnya yang mereka gunakan selain ayat di atas adalah riwayat Ibnu Jarir, Ibnu Abi Hatim dari kakeknya al Hanafi, dia berkata "Saya bertanya kepada Ibnu Abbas tentang firman Allah Swt. “ قطعوا أيديهما

" apakah ayat ini bersifat khusus atau umum? Ibnu Abbas berkata "umum". Kemudian juga hadits riwayat $\mathrm{Abu}$ Hurairah bahwa Rasul Saw bersabda: )

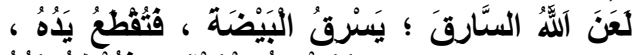

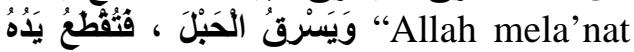
pencuri yang mencuri al-biadhah (sebutir telur) maka dipotong tangannya, juga pencuri sepotong tali dipotong tangannya. ${ }^{20}$ Dalam suatu riwayat dari A'mas dijelaskan bahwa menurut A'mas biadhah yang dimaksudkan adalah telur yang terbuat dari besi yang digunakan dalam peperangan sebagai peluru yang harganya sama dengan perisai, sedangkan tali itu tali yag nilainya sama dengan beberapa dirham. ${ }^{21}$

${ }^{20}$ Muhammad Jamaluddin al-Qasimi, Tafsir al-Qasim almusamma Mahasin alTa'wil, Dar al-Fkr, Beirut, 1978, juz. 6, h. 193194. Lihat al-Bukhari, op.cit. pada hudud bab 7 dan 13, Muslim, op.cit. pada hudud hadits 7 , an-Nisa'i op.cit. pada al-Sariq bab 1, Ibnu Majah, op.cit. pada hudud bab 29 dan Ahmad ,op.cit. juz 2 hadits 253.

${ }^{21}$ Al-Qurtubi, op.cit. h. 113. 
Menurut golongan ini hadits Ibnu Abbas dan hadits Abu Hurairah ini semakin menjelaskan bahwa hukum potong tangan dilakukan kepada semua pencuri apapun yang mereka curi dan berapapun jumlahnya.

Segolongan ahli Madinah, diantaranya Malik bin Anas, berpendapat bahwa pencuri yang dipotong tangannya adalah yang mencuri sejumlah tiga dirham atau lebih dengan dalil yang telah dikemuakan sebelumnya yaitu hadits Aisyah r.a. Tetapi Abu Hanifah berpendapat dipotong tangan pencuri jika dia mencuri sejumlah sepuluh dinar atau lebih. ${ }^{22}$ Juga ada riwayat dari al-Baqi bin Qani' dia mengatakan bahwa dia menerima riwayat dari Abdullah bin Ahmad bin Hambal yang menyampaikan riwayat dari bapaknya dari Nashar bin Tsabit dari Hajaj dari Umar bin Syuaib dari Bapaknya dari kakeknya dia berkata bahwa Rasul Saw bersabda " Tidaklah dipotong pada curian yang kurang dari sepuluh dirham." Dan Riwayat Ibnu Mas'ud menjelaskan bahwa Nabi Saw. Berkata “ Tidaklah dipotong tangan pencuri kecuali pada curian satu dinar atau sepuluh dirham". Sedangkan Umar bin Syu'aib mengatakan bahwa Sa'id bin Musayyab berkata "Sesungguhnya Urwah, Zuhri dan Sulaiman bin Yasar berpendapat bahwa tidaklah dipotong tangan pencuri kecuali pada barang curian yang nilainya lima dirham. Pada masa Rasul saw telah terjadi potong tangan pencuri untuk curian sepuluh dirham. Harga perisai adalah sepuluh dirham. ${ }^{23}$

${ }^{22}$ Abu Ja'far Muhammad bin Jarir ath Thabary, Jami' al-Bayan 'an Ta'wil ayyi alQur'an, Dar al-Fkri, Beirut, tt. juz . 5,h. 311.

23 Al-Jashsash, Ahkam al-Qur'an, Dar al-Fikr, Mesir, juz.2. tt.h.585.
Menurut al-Jashash wajib memperlakukan hukum atas isim kecuali dikhususkan oleh dalil, atau ditetapkan bahwa hukum ada hubungannya dengan makna lain yang wajib diperhatikan tentang wajibnya, yaitu tempat penyimpanan dan ukuran. Ayat ini mujmal dipandang dari segi ukuran dia membutuhkan penjelasan dari yang lain dalam menetapkannya, oleh karena itu tidak boleh memandang umum untuk memperlakukan hukum potong tangan pada setiap ukuran. Dalil kemujmalannya dan larangan memperlakukan umum adalah hadits Abdul Baqi. Abdul Baqi mengatakan Mu'az bin Mutsanna menerima dari Amir bin Sa'id dari Bapaknya dia berkata : Rasul Saw bersabda "Tidaklah dipotong tangan seorang pencuri kecuali pada harga perisai", kemudian riwayat Abi Luhai'ah dari alNashr dari Imarah dari Aisyah r.a. bahwa Nabi Saw berkata: "Tidaklah dipotong tangan seorang pencuri kecuali pada barang curian yang senilai dengan harga perisai atau lebih" juga riwayat Aiman al-Jasyaby yang menjelaskan "paling kurang yang dicuri itu seharga perisai". ${ }^{24}$

Berdasarkan hadits -hadits tersebut ditetapkanlah bahwa hukum ayat tentang wajib potong tangan adalah seharga perisai, dan karena itu tidak boleh diamalkan secara umum. Sehingga ayat seolah-olah taqdirnya adalah "Seorang pencuri laki-laki dan pencuri perempuan maka potonglah tangan keduanya jika curian itu sampai seharga perisai”. Lafaz ini menghendaki penjelasan lain untuk menjadikannya cukup untuk

24 Abu Bakar Ahmad al-Razi alJashash, Ahkam al-Qur'an, Dar.al-Fikr, Mesir, t.t. juz 2, h. 583 . 
menetapkan hukum dengan dirinya sendiri.

Jadi pada asalnya fuqaha' sepakat bahwa tidak dilaksanakan potong tangan kecuali pada barang curian yang sampai ukurannya senishab, jika kurang maka tidak wajib potong tangan. Hanya saja mereka berbeda pendapat dalam menentukan batas nisab yang mengharuskan potong tangan bagi seorang pencuri, sebagaimana dikemukakan di atas.

Masalah ketiga kemudian para ulama sepakat bahwa tangan yang dipotong adalah tangan kanan berdasarkan qira'at Ibnu Mas'ud “ فا قطعوا أيمنهما ”, namun mereka berbeda pendapat dibagian mana tangan tersebut dipotong. Fuqah' Mesir (al-amshar) berpendapat dipotong pada pergelangan tidak di siku atau dipangkal lengan, Khawarij berpendapat dipotong dipangkal lengan, dan suatu golongan berpendapat dipotong di jari-jari saja. Dalil Jumhur adalah riwayat yang menjelaskan bahwa Rasul Saw. Memotong tangan pencuri dari pergelangan, begitu juga pendapat Ali, Umar bin Khathab, mereka memotong tangan pencuri pada sambungan pergelangan, inilah yang diamalkan. Tapi jika dia mencuri untuk yang keduakalinya maka dipotong tangannya yang kiri berdasarkan ittifaq para fuqaha. $^{25}$

Berdasarkan penjelasan mufassir tentang maksud dari ayat yang menjelaskan tentang perintah memotong tangan bagi pencuri, baik pencuri itu laki-laki ataupun perempuan, dapat dipahami bahwa ayat ini adalah umum dengan lafaz

25 Ali ash-Shabuni, Rawai'ul Bayan Tafsir Ayat al-Ahkam min al-Qur'an, Dar alKutub al-Islamiah, Mesir,tt. Juz 1. h.440. yang mujmal oleh karena itu untuk menerapkan amar yang ada didalam ayat diperlukan penjelasan dari dalil lain yaitu hadits-hadits Rasulullah Saw, penjelasan bahasa tentang makna lafaz dan pendapat para mufassir dan fuqaha'. Dari penjelasan tersebut dapat dipahami bahwa had potong tangan bagi pencuri adalah wajib. Wajibnya had tersebut harus ada ukuran atau nishab harta yang dicurinya, tidak boleh diperlakukan umum terhadap semua pencurian.

Adapun batasan barang curian yang menyebabkan wajibnya potong tangan terhadap pencuri, terjadi perbedaan pendapat dikalangan ulama. Jumhur ulama menetapkan nishabnya adalah seperempat dinar dengan dalil hadits Aisyah. Maliki menetapkan tiga dinar atau lebih dengan dalil hadits Aisyah, bahwa seperempat dinar sama dengan tiga dirham. Kemudian Hambali dan Hanafiah mengatakan kadarnya adalah sepuluh dirham dengan dalil hadits Umar bin Syu'aib.

Memperhatikan hadits, qaul sahabat dan pendapat ulama di atas maka kadar barang curian yang mewajibkan potong tangan bagi pencuri minimal adalah seperempat dinar, jika kurang dari jumlah tersebut maka hukuman potong tangan tidak dilaksanakan. Adapun sanksi yang diberikan kepada pencuri yang mencuri kurang dari seperempat dinar dipahami dari hadits Abu Hurairah yang menjelaskan bahwa Rasul melaknat pencuri yang mencuri telur dan mencuri tali maka keduanya dipotong tangannya. Oleh karena itu dapat dipahami bahwa riwayat Abu Hurairah ini ini adalah umum sama dengan makna ayat, yaitu berapa saja yang dicuri maka bagi pencurinya wajib potong tangan 
sebagaimana pendapat sebahagian ahli Zahir.

Ayat " فاقطعو أيديهما "artinya potonglah oleh kamu tangan keduanya, yaitu tangan pencuri yang laki-laki dan pencuri yang perempuan. Artinya setiap pencuri baik laki-laki ataupun perempuan dipotong tangannya sebagaimana yang dilaksanakan terhadap para perampok atau muharibun jika mereka merampas harta seperti kedua pencuri tersebut. Rasyid Ridha menjelaskan bahwa jika mencuri lagi untuk yang kedua kalinya maka dipotong tangannya sebab "aid" adalah jamak dari yad. ${ }^{26} "$

berasal dari lafaz $q$-th-' $a$ yang maknanya memotong, al-qath'u artinya al-ibanah (pemisahan) dan izalah (penghilangan). Dan pemotongan atau penghilangan tangan ini dilakukan jika syaratnya tercapai yaitu pencurian harta milik orang lain, harta diambil dari termpat persembunyiannya yang wajar dan harta yang dicuri mencapai jumlah nishab, bagi ulama yang menetapkan nishabnya.

Quraisyihab mengemukakan bahwa ada sebahagian orang yang memahami ayat ini dengan makna majazi, yakni melumpuhkan kemampuannya, yakni dengan memenjarakannya. Namun makna ini tidak dikenal oleh orang Arab untuk qath'u al-yad. ${ }^{27}$ Namun alBasamy mengatakan bahwa orang yang memaknai dengan apa yang tidak dijelaskan Allah seperti yang ditetapkan dalam undang-undang dengan memberikan hukuman penjara kepada pencuri sama saja dengan

${ }^{26}$ Muhammad Rasyid Ridha, Tafsir al-Qur'an al-Hakim al-Masyhur bitafsir AlManar, Dar al-Kutub al-Ilmiah, Beirut, 1935, juz 6, h. 315.

${ }^{27}$ M.Qurai Syihab, Tafsir al-Misbah, Lentera Hati, Tangerang, juz 3, h. 195. memberikan kenikmatan kepada pencuri sebab disana mereka makan dan minum dan kelezatan lain. $^{28}$ Kemudian tidak ada ulama yang memahami dengan makna majazi, tetapi mereka memahami dengan makna hakiki, sebab tujuan dilakasanakannya hukuman potong tangan bagi pencuri adalah untuk hukuman dan balasan atas perbuatan mereka yang melakukan pencurian. Diberikannya hukuman juga bertujuan untuk memberikan alasan agar jangan mencuri bagi yang lain.

Suatu lafaz dipahami dengan makna hakiki, kecuali jika ada hal-hal yang memalingkan makna hakiki kepada makna majazi. Adapun hal-hal yang menyebabkan tidak dipahaminya suatu lafaz dengan makna hakiki adalah jika terdapat petunjuk penggunaan secara 'urf bahwa makna hakiki ditinggalkan, adanya petunjuk lafaz bahwa yang dimaksudkan bukan makna hakiki tetapi makna lain, adanya petunjuk berupa aturan dalam pengungkapan suatu ucapan bahwa lafaz tersebut adalah untuk makna lain bukan untuk makna hakiki, adanya petunjuk dari sifat pembicara yaang menuntut sesuatu menurut hakiki, namun dari sifat si pembicara dapat dipahami bahwa ia tidak menginginkan sesuatu yang diucapkanya tersebut, dan adanya tempat dan sasaran pembicaraan yang menghalangi dari memahami lafaz secara hakiki. ${ }^{29}$

${ }^{28}$ Al-Basamy. Op.cit. h. 183.
Amir Syarifuddin, Ushul Fiqh, Kencana, Jakarta, juz I, h. 35-36. Al-Ghazali menjelaskan bahwa suatu lafaz harus dipahami sesuai dengan makna yang sudah ditetapkan untuknya secara hakiki menurut pemilik bahasa, dan sebelum dipahami dengan makna lain harus diperhatikan dulu bagaimana pemilik bahasa atau ahli bahasa menggunakan dan memaknai lafaz tersebut. Hal ini karena suatu 
Dari syarat-syarat suatu lafaz dipahami dengan makna majaz tersebut maka dapat dipahami bahwaa syarat-syarat tersebut tidak ditemukaan pada ayat ini. Oleh sebab itu tidak ada alasan untuk memahami ayat tentang perintah memotong tangan pencuri dengan makna penjara.

Lebih lanjut Rasyid Ridha mengatakan bahwa Allah ingin mencela keduanya dengan bacaan al-Qur'an. Jika hukum syari'ah mengikat keduanya secara mutlaq dan dan biasa mensifati azzukur dan domirnya dalam kalimat, kecuali apa yang dikhususkan syari'ah terhadap laki-laki, seperti imamah dan qital, Memutarkan kemutlakan yad yaitu bahwasanya mencukupkan tempat memotongnya pada pergelangan tangan. ${ }^{30}$

فاقطعوا أيديهما menunjukkan yang boleh dipotong itu adalah tangan kanan, tetapi ayat tidak menunjukkan hal itu. Karena lafaz aidy menurut al-Qurthubi adalah menunjukkan kepada empat perkara yang terhimpun pada dua perkara yaitu tangan dan kaki, sebab lafaz "huma" adalah tatsniyah, sebab pencuri lakilaki dan pencuri perempuan itu tidak dimaksudkan sosok tertentu tetapi keduanya adalah jenis kelamin yang jumlahnya tidak berbilang. ${ }^{31}$ Penetapan tangan kanan yang dipotong tersebut menurut al-Jashash didasarkan pada qira'at Abdullah "فاقطعوا أيمنهما" sesuai dengan riwayat yang diceritakan oleh Sufyan dari Jabir dari Amir. Ibnu Auf dari Ibrahim juga meriwayatkan bahwa "faqtha'u aimanhuma". Abu

lafaz diciptakan mempunyai makna hakiki. Abu Hamid Muhammad bin Muhammad alGhazali, Al-Mustashfa min Ilm al-Ushul, Dar al-Kutub al-Ilmiah, Beirut, 1971, h. 288-296.

${ }^{30}$ Ibid. h 289.

${ }^{31}$ Al-Qurthubi, op.Cit. h. 117.
Bakar mengatakan bahwa tidak ada perbedaan pendapat ditengah umat bahwa yang dimaksudkan adalah memotong tangan kanan pada pencurian yang dilakukan pertama kali. 32 Pendapat yang sama juga dikemukakan oleh al-Qasimi, hanya saja menurut al-Qasimin ini adalah qira'at syaz. Tetapi ada dalil lain yaitu yang sudah terjadi pada jaman jahiliah kemudian pada masa Islam ketika Nabi melakukan hal yang sama. ${ }^{33}$

As-Sammy mengemukakan bahwa jumhur ulama berpendapat demikian juga bahwa yang dipotong pertama kali adalah tangan kanan dengan berpegang pada qira'at Ibnu Mas'ud, yad secara mutlaq adalah telapak tangan karena itu batasannya adalah pergelangan tangan, dan itulah yang terjadi menurut sunnah. ${ }^{34}$

artinya potong tangan bagi pencuri baik laki-laki ataupun perempuan merupakan balasan terhadap perbuatan keduanya dan karena usaha keduanya yaitu mencuri, mengambil harta orang lain yang diharamkan baginya dan yang orang lain tidak menginginkan hartanya diambil. "nakala" artinya peringatan dan celaan atau hinaan karena perbuatan mencuri. Semua in adalah iqab atau hukuman bagi pencuri, sekalipun mereka bisa lari dari manusia tetapi hukuman yang sesuai dengan perbuatan mereka yang melakukan pencurian adalah yang lebih dahsyat pengaruhnya dan larangan dari melakukannya. Pencurian akan menyebabkan tidak amannya manusia dari hartanya dan manusia akan merasa

32 Imam Abu Bakar Ahmad al-Razi Al-Jashsh, Ahkam al-Qur'an, Dar al-Fkri, Mesir, juz. 2. T.t. 582.

${ }^{33}$ Al-Qasimi.Op,cit. H. 192.
${ }^{34}$ As-Sammi. Op.cit. h. 186. 
merasa khawatir oleh karena itulah Allah menetapkan hukuman bagi pencuri. Pencurian berpengaruh besar terhadap masyarakat dan pengaruh tersebut lama dan berkelanjutan yaitu tidak adanya rasa aman dan hidup dalam kecemassan dan kekhawatiran tentang keamanan hartanya. ${ }^{35}$

Menurut Mu'tazilah ayat ini menunjukkan bahwa pelaksanaan had adalah karena tujuan penghinaan dan peringatan bagi pencuri. Ini menunjukkan balasan yang berat bagi pencuri dan juga menunjukkan illat hukum Allah sebab "alba" pada "bima kasaba" jelas sekali menunjukkan bahwa pemotongan tangan hanya wajib dengan alasan pencurian. ${ }^{36}$

Pendapat yang sama juga dijelaskan oleh at-Thabari bahwa potong adalah balasan terhadap perbuatan mencuri yang dilakukan keduanya dari Allah. Thabari juga menjelaskan bahwa Umar binKhatab menyuruh agar memberikan hukuman yang keras (berat) kepada pencuri dalam kasus pencurian.Umar mengatakan "potonglah tangan -tangan mereka lalu kai-kaki mereka".

maksud firman Allah ini menurut at-Thabari adalah bahwa Allah maha Perkasa dalam memberikan hukuman kepada laki-laki atau perempuan yang melakukan pencurian serta selain mereka berdua yang melakukan kedurhakaan kepada Allah.

35 Abu Ali al-Faadhli Ibn Hasan bin Fadhal al-Thibrasi, Majma' al-Bayan fi Tafsir al-Qur'an, Dar al-Kutub al-Ilmiah,Beirut, t.t.h. 250 .

${ }^{36}$ Muhammad al-Razi Fakhrudin ibn al-AlamahDhia' al-Din Umar al-Musytahir bi Khathib al-Ra;yi, Dar al-Fkr, Mesir, t.t. juz. 11, h. 230., lihat juga Abi Fadhal Syihab al-Din al-Said Muhammad al-Alusy al-Baghdadi, Ruhul Ma'ani fi Tafsir al-Qur'an al-Azim wa al-Sab;u al-Matsany, Dar al-Kutub al-Ilmiah, Beirut, t.t jilid.3 h. 203.
Allah maha bijaksana dalam memberikan keputusan dan hukuman kepada mereka. Ayat ini juga bermakna "oleh karena itu janganlah kamu berlebih-lebihan dalam memberikan hukuman, hai orang-orang mukmin, terhadap orang pencuri dan selain mereka dari orang-orang yang melakukan kejahatan yang wajib diberikan hukuman. Karena sesungguhnya Allah dengan hikmahNya memutuskan keputusan untuk mereka dan pengetahuan Allah menunjukkan kebaikan kepada mereka dan kepadamu. ${ }^{37}$

Dari beberap pendapat ulama dapat dipahami bahwa hukuman potong tangan bagi pencuri adalah syari'at yang sudah ditetapkan Allah. Dan para ulama sepakat dalam hal ini Pendapat ini dikuatkan lagi oleh hadits riwayat Aisyah yang menjelaskan bahwa Rasul Saw mencela orang-orang yang tidak ingin melakukan ketentuan Allah ini karena membela seorang wanita yang mencuri hanya karena dia berasal dari kalangan bangsawan, dengan sabdanya

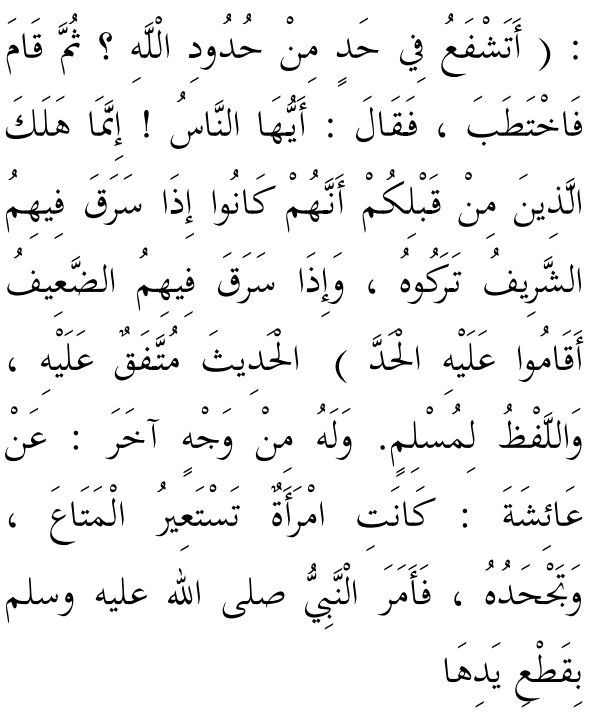

37 Ath-Thabari, Op.cit. Lihat juga M.Rasyid Ridho, Op.cit. 315. 
: "Apakah engkau akan memberikan pertolongan untuk membebaskan suatu hukuman dari hukum-hukum yang telah ditetapkan Allah?". Kemudian beliau berdiri dan berkhutbah. Beliau bersabda: "Wahai manusia, orangorang sebelummu binasa adalah karena jika ada seseorang yang terpandang di antara mereka mencuri, mereka membebaskannya, dan jika ada orang lemah di antara mereka mencuri, mereka menegakkan hukum padanya." Muttafaq Alaihi dan lafadznya menurut riwayat Muslim. Menurut riwayatnya dari jalan lain bahwa 'Aisyah Radliyallaahu 'anhu berkata: Ada seorang perempuan meminjam barang lalu memungkirinya, maka Nabi Shallallaahu 'alaihi wa Sallam memerintahkan untuk memotong tangannya.

Dalam sejarah umat Islam terkenal bahwa Umar bin Khathab pernah tidak memberikan hukuman potong tangan terhadap seorang pencuri pada masa paceklik. Hal ini sebenarnya tidak bertentangan dengan ayat atau hadits yang memerintahkan potong tangan dengan syarat-tertentu, karena ada riwayat dari Rafi' bi Khadij yang menjelaskan bahwa ia mendengar

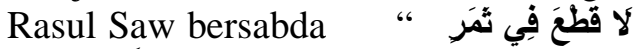

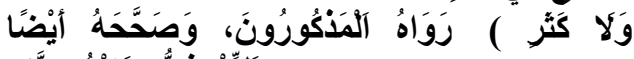
Artinya tidaklah ada potong tangan pada pencurian sebiji tamar atau lebih, yang diambil dari pohonnya, tetapi pencuri hanya dikenakan hukaman untuk mengganti saja. Tidak dilakukannya oleh Umar hukuman potong tangan bagi pencuri pada masa paceklik tersebut bukan berarti dia menghapuskan hukuman potong tangan, hanya saja Umar melakukan dengan ihthiyat atau hatihati terutama pencurian dilakukan hanya untuk makan bukan untuk diperdagangkan. Menurut alQurtuby seorang pencuri yang wajib dilakukan padanya potong tangan harus memenuhi beberapa syarat, yaitu baligh, beraqal, bahwa harta bukan milik si pencuri, bahwa si pencuri tidak ada haq dan kekuasaan pada harta yang dicuri. Karena itu tidaklah dilakukan had potong tangan pada pencuri yang belum baligh, tidak beraqal, yang mencuri miliknya sendiri, atau pada harta yang dimilikinya bersama dengan pihak lain seperti harta syirkah antara pencuri dengan orang lain, atau orang tua yang mencuri harta anaknya, atau seorang tuan yang mencuri harta budaknya karena budak itu sendiri adalah milik tuannya atau sebaliknya tidak dihad seorang budak yang mencuri harta tuannya, sebagaimana riwayat Darul Quthni yang berasal dari Ibnu Abbas bahwa Rasul Saw bersabda ليس علئ العبد الأ بق اذا سرق قطع و لا علئ “ ل

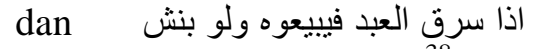
dan tuannya boleh menjualnya. ${ }^{38}$

Demikianlah Allah telah menetapkan bahwa had potong tangan dilakukan pada seorang pencuri baik dia laki-laki ataupun perempuan.

\section{Hikmah Penetapan Hukum Had Potong Tangan Bagi Pencuri}

Para ulama sepakat bahwa tujuan pensyari'atan hukum oleh Allah Swt adalah untuk kemaslahatan umat

manusia, sesuai dengan tujuan pengutusan Rasul Saw oleh Allah Swt. Allah berfirman dalam surat al-Anbiya' ayat 107 :

38 Al-Qurthuby. Op.cit. h. 117. Wahbah al-Zuhaili, al-Fiqh al-Islamy wa Adillatuhu, Dar al-Fikr, Beirut1989, juz. 6, h. 100. 


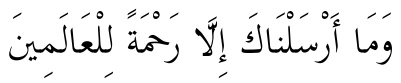

Dan Tiadalah Kami mengutus kamu, melainkan untuk (menjadi) rahmat bagi semesta alam.

Dalam ayat di atas Allah menjelaskan bahwa Allah mengutus Muhammad sebagai Rasul adalah sebagai rahmat bagi alam semesta. Artinya Muhammad diutus menyampaikan risalahnya yang membawa din al-Islam dari Allah untuk disampaikan kepada umat manusia agar manusia dapat menjadikan ad-din tersebut sebagai pedoman dalam menjalani kehidupan di dunia dan untuk mencapai kebahagiaan di akhirat kelak. Kemaslahatan manusia hanya dapat dicapai jika kehidupan manusia terjaga dan terjamin keselamatannya, keselamatan agamanya, jiwa, aqal, nasab dan hartanya. Karena itu para ulama mengatakan bahwa tujuan pensyari'atan hokum adalah untuk menjaga kemaslahatan manusia.

Kemudian al-Ghazali (w.505 H/1111 M) menjelaskan bahwa maslahah yang menjadi tujuan syara' adalah memelihara tujuan syara' itu sendiri.Tujuan syara' terhadap mahkhluq ada lima, yaitu untuk memelihara agama, memelihara jiwa, memelihara aqal, memelihara keturunan dan memelihara harta. Setiap sesuatu yang mencakup terhadap pemeliharaan terhadap ashal yang lima ini maka hal itu adalah maslahah. Sedangkan setiap sesuatu yang menyebabkan hilangnya ashal yang lima ini disebut mafsadah. Pemeliharaan kelima ashal ini mempunyai tingkatan-tingkatan. Pertama tingkatan adh-dharuriyyat, kedua al-hajjiyat dan yang ketiga yang tidak termasuk pada dharuriyyat dan hajjiyat, yaitu al-tahsiniyat, altazyiniin, al-taisir. ${ }^{39}$

Syatibi menjelaskan bahwa tujuan Allah SWT memberlakukan syariah adalah untuk kemaslahatan hambanya baik di dunia maupun di akhirat. Kemudian ia membagi maslahat menjadi tiga bagian; yang pertama dlaruriyah (primer), yang kedua hajiyah (sekunder), yang ketiga tahsiniyah (tertier). Dlaruriyah adalah sesuatu yang harus ada untuk mewujudkan kemaslahatan dunia maupun akhirat. Jika tidak ada, maka bisa menyebabkan kehancuran dalam kehidupan dunia maupun akhirat. Dlaruriyah ini, menurut penelitian, mencakup pada pemeliharaan terhadap lima hal; hifzhud din (agama), hifzhun nafs (jiwa), hifzhun nasl (keturunan), hifzhul maal (harta), dan hifzhul 'aqal (akal). ${ }^{40}$

Dari beberapa tujuan pensyari'atan hokum Islam sebagaimana yang dikemukakan di atas adalah untuk memelihara harta manusia, baik pemeliharaan sebagai hak milik ataupun pemeliharaan dari kerusakan ataupun kemusnahan. Oleh karena itu untuk menjaga kemaslahatan harta manusia Allah menetapkan suatu aturan bahwa bagi siapa yang melanggar ketentuan tersebut diberi

39 Al-Ghazali, al-Muastashfa fi 'ilm al-Ushul, Pen.Dar al-Kutub al-'Ilmiah, Beirut, 1971, h. 275.

4040 Al-Imam Abi Ishaq Ibrahim bin Musa, Al-Muwafaqt fi Ushul al-Ahkam, Dar al Fkri, Beirut, t.t. juz. II. Selanjutnya di sebut Syatibi. Dalam kitabnya ini Syatibi membahas maqashid al-ahkam secara khusus pada juz kedua dari kitabnya, dalam 290 halaman. Jika dibandingkan dengan ulama-ulama sebelumnya pembahasan Syatibi memang lebih luas, karena pada masa-masa sebelum Syatibi maqashid syari'ah umumnya dibahas ketika menjelaskan maslahah dan 'illat pada qiyas 
sanksi yang kemudian dikenal dengan hokum jinayah.

\section{Kesimpulan}

Berdasarkan penjelasan yang dikemukakan oleh para mufassir dan para fuqaha' terhadap ayat 38 surat alMaidah ini maka dapat dipahami bahwa Allah mewajibkan hukuman potong tangan bagi pencuri, meskipun para ulama berbeda pendapat tentang nisab harta yang dicuri, batasan dan ketentuan untuk dilakukannya potong tangan. Penetapan ketentuan batasan dan ukuran yang mewajibkan pelaksanaan had tersebut di dasarkan selain ayat tersebut juga didasarkan kepada sunnah, qiyas dan qaul sahabah. Semua ketentuan tesebut juga ditentukan pemahaman para mufassir dan fuqaha' terhadap qaedah-qaedah kebahasan yang berlaku dalam bahasa Arab. Sehingga dalam menetapkan batasan tangan yang akan dipotong ada yang mengatakan di pergelangan dan ada yang jari-jari saja dan juga ada yang mengatakan dipesendian tangan. Demikian juga batasan harta yang dicuri yang mewajibkan potong tangan ada yang mengatakan tidak ada batasan, asal mencuri maka wajib potong tangan, ada yang mengatakan seperempat dinar, ada yang tiga dirham, ada yang lima dirham dan ada yang sepuluh dirham dan lainnya. Sedangkan tujuan disyari'atkannya had potong tangan bagi pencuri adalah untuk memberikan jaminan kemaslahatan terhadap harta yang dimiliki oleh seseorang atau manusia dari kejahatan pihak lain. Karena tujuan umum pensyari'atan hokum Islam adalah untuk menjaga kemaslahatan manusia yaitu kemaslahatan agama, jiwa, aqal, nasab dan harta.

\section{Daftar Pustaka}

Al;-Baghdadi, Abi Fadhal Syihab alDin al-Said Muhammad al-Alusy, Rawai' al-Bayanfi Tafsir al-Qur'an alAzhim wa al-Sab'u al-Matsany, Dar alKutub al-Ilmiah, Beirut, t.t, juz. 3.

Al-Bassam, Abdurrahman, Tudhih al Ahkam min Bulugh al-Maram, juz. 4.

Al-Baqy, Muhammad Fuad Abd, AlLu'lu' wa al-Marjan, Dar Ahya' al Arabiah Isa al-Babi al-Halaby wa Syirkah,Kairo, 1949.

Al-Ghazali, Abu Hamid Muhammad bin Muhammad, Al-Mustashfa min Ilm al-Ushul, Dar al-Kutub al-Ilmiah, Beirut, 1971.

Al-Tsa'laby, Imam al-Allamah alSyaikh Saidy Abd al-Rahman, Dar alKutub al-Ilmiah, Beirut, juz. 1.

Al-Jashash, Imam Abi Bakar Ahmad al-Razy, Dar al-Fikr, Mesir, t.t.juz 1.

Al-Zuhaili, DR.Wahbah, Al;-Tafsir alMunir fi Aqidah wa al-Syari'ah wa alManhaj, Dar al-Fkr, al Ma'ashir, Beirut,juz. 5.

Al-Fiqh al-Islam wa Adillatuhu, Dar al-Fikr al-Ma'ashir ,Beirut, t.t. juz. 6.

Ridha, Said Imam Muhammad Rasyid, Tafsir al-Qur'an al-Hakim al-Masyhur bi Tafsir al-Manar, Dar al-Kitab alIlmiah, Beirut, 1925. Juz 6.

Syarifuddin, Amir, Ushul Fiqh, jld. 2, Kencana, Jakarta, 2009

Al-Shabuny, Muhammad Ali, Rawai' al-Bayan Tafsir Ayat al-Ahkam min alQur'an, Dar al-Kutub al-Islamiah, Mesir, t.t. juz. 1.

Al-Shan'ani, Imam Muhammad bin Ismail al-Amir al-Yamany, 
Subulussalam, Syarah Bulugh alMaram, Syirkah Makatabah Mushthafa al-Babi al-Halaby wa Auladih, Kairo, 1950.

Al-Qurthuby, Abi Abdillah Muhammad bin Ahmad al-Anshary alQurthubi, Dar al-Fkri, Mesir, t.t.juz 5.

Al-Qasimy, Muhammad Jamaluddin, Tafsir al-Qasimy al Musamma Mahasin al Ta'wil, Dar al-Fikr, Beirut, 1978, juz. 6.

Ibnu Anas, Imam Malik, AlMu'aththa', Dar al-Fikr, Mesir, t.t.

Ismail Ibnu Ibrahim, Imam Abu Abdullah Muhammad bin, Shahih al-
Bukhary, Maktabah wa Mathba'ah Usaha Keluarga, Semarang, 1981.

Umar, Imam Muhammad al-Razi Ibn Fakhr al-Din ibn al-Alamah al-Dhiya' al-Din. Tafsir al-Fakhr al-Razi alMasyhur bi Tafsir al-Kabir wa Mafatih al-Ghaibi, Dar al-Fikr, Mesir, juz. 11.

Al-Thabary, Abi Ja'far Muhammad bin Jarir, Jami' al Bayan 'an Ta'wil Ayyi al-Qur'an, Dar al-Fikr, Mesir, juz, 5.

Al-Thibrasy, Abu Ali al-Fadhal bin alHasan bin Fadhal, Majma' al-Bayan fi Tafsir al-Qur'an, Dar al-Kutub alIlmiah, Mesir, tt. Juz. 3. 